\title{
Point Dilution Tracer Test to Assess Slow Groundwater Flow in an Auxiliary Karst System (Lake of Fontaine de Rivîre, Belgium)
}

\author{
Philippe Meus, Jérémy Flament, Luc Willems, Luc Funcken, \\ Gauthier Roba, Claire A. Chauveau, Jean Godissart, and Camille Ek
}

\begin{abstract}
The quantification of mass transfer through auxiliary karst systems is addressed by using a specific point dilution long-term tracer test. The physical functioning of such systems is usually only inferred by hydrodynamical and environmental tracer data, whose interpretation often relies on invalidated assumptions. The new approach is a way for experimentally validating or complementing the classical approaches. The lake of Fontaine de Rivire is an auxiliary karst system in the Frasnian limestones of the Ourthe Valley in Belgium. Its particular confinement was studied by conjunctional use of natural responses and single-point dilution tracer test, with an injection of $41 \mathrm{~g}$
\end{abstract}

\section{P. Meus $(\bowtie)$}

European Water Tracing Services, Nandrin, and Club de

Recherches Spéléologiques Ourthe Amblève, Sprimont, Belgium

e-mail: ewts@skynet.be

\section{J. Flament}

Institut Scientifique de Service Public, Liège, and Club de Recherches Spéléologiques Ourthe Amblève, Sprimont, Belgium e-mail: j.flament@issep.be

L. Willems · C. Ek

Université de Liège, Liège, and Club de Recherches

Spéléologiques Ourthe Amblève, Sprimont, Belgium

e-mail: 1.willems@uliege.be

\section{Ek}

e-mail: camille.ek@uliege.be

\section{Funcken}

Service Public de Wallonie, Direction de la Géotechnique,

Liège, Belgium

e-mail: luc.funcken@spw.wallonie.be

G. Roba - C. A. Chauveau

Club de Recherches Spéléologiques Ourthe Amblève,

Sprimont, Belgium

e-mail: robbygees@hotmail.com

C. A. Chauveau

e-mail: claire.a.chauveau@outlook.com

J. Godissart

Union Belge de Spéléologie, Namur, Belgium

e-mail: godissart.jean@gmail.com of uranine on 22 March 2017. The tracer test was monitored during one year using fluorometers, water and charcoal samplings at five points in the lake and six points at the surface (no connection having been established outside). A slow flow (in the order of magnitude of $1 \mathrm{~m} / \mathrm{h}$ ) of the lake could be observed and some mixing processes identified. The dilution of the tracer along the year indicates an average discharge of only $0.16 \mathrm{l} / \mathrm{s}$. This low discharge is compatible with the high confinement of the lake also proved by its high homogeneity and stability (temperature and conductivity). However, the level fluctuations are apparently not compatible with this renewal, and especially with the low rate of dilution of the tracer observed during winter in the lake. This can thus be explained by pressure transfers from the surroundings, without necessarily high fluxes of water. The delays for the responses have also been quantified by cross-correlations for the whole period of monitoring from 2007 to 2018 .

\section{Keywords}

Dilution test $\bullet$ Uranine $\bullet$ Active charcoal $\bullet$ Natural tracer $\bullet$ Karst flow $\bullet$ Climate

\section{Introduction}

Since the early steps of hydrogeology, the question of the groundwater origin has always been generating a lot of controversies. At the beginning of the twentieth century, after recognizing the precipitations as the origin, the main question was changed to how water flows, and is stored, into the soil and subsoil, and on the role that fissures, especially those enlarged into karstic conduits, can play for these flows, from the infiltration processes unto the emergence of groundwater in the springs (Martel 1921). Several decades later, the duality of diffuse and conduit flow became the main topic of research for karst aquifers (Mangin 1975; Müller 1981; 
Worthington 2003), while multiple porosity behaviours were also recognized in many other aquifers. One should say that, and this remains valid today, most of the hydrogeological questions can be reduced to a main question about the relationship between the structure of voids and groundwater flows in between them. So, definitely, the early question of flow was not so trivial. What probably makes the difference nowadays is that an increasing number of methods and innovative instruments have been implemented in hydrogeology, providing data to answer the above question and to allow for better management of groundwater resources (exploitation, protection, remediation, etc.).

Mangin (1994), Jeannin (1996), Bakalowicz (1999) and Kiraly (2003) emphasized the role of a hierarchical structure for karstic flows, and they identified the role of these "somewhat hidden" auxiliary systems (the so-called annex-to-drain systems of the French terminology) in the functioning of karst aquifers.

However, a direct insight into these auxiliary systems seems not so common (or not often recognized as such) and their knowledge is mainly limited by the small panel of experimental techniques than can be implemented inside the systems. Bakalowicz et al. (1994), as well as Marsaud (1996), already attempted high-rate pumping tests in such system with quite good connection with the main karst conduits. Meus (1997) experienced a continuous tracer test in the same system. Dewaide et al. (2017) have used fluorescent dye tracing to assess where the main flow was occurring, and how it was exchanging with low flow water, in large karst conduits. Nevertheless, most of the knowledge about such systems, in most of the carbonate aquifers, is usually coming from indirect measurements using spring hydrographs, natural tracers (temperature, chemistry or isotopes), water levels, where boreholes or caves exist, or any combination of those tracers (Grasso et al. 2003).

In this study, we took advantage of a "windowing" on an underground lake, with undetected connection with any transmissive conduit. Such system could be considered as an extreme auxiliary system, offering the unique opportunity to experiment artificial tracers in conditions where natural tracers only would have normally been used, and to make a comparison between both methods. This artificial tracer test, as such, can thus be considered as a border case for natural tracing.

This long-term tracer test is also quite uncommon since it could only be qualified "from the interior", according to a single-point dilution method (Novakowski et al. 1995), without any surface breakthrough of the tracer, and thus without any residence time distribution available for the interpretation, as it is usually the case for tracer tests (Guizerix et al. 1990).

The specificity of the dynamics of the lake and its exceptionally weak connectivity to the neighbouring parts of the aquifer helped us a lot in interpreting long-term water level and temperature variations, as well as thermal and $\mathrm{CO}_{2}$ exchanges with the cave atmosphere.

Several methodologies experimented here revealed themselves promising tools for long-term experimentation, among others the point dilution tracer test method, the video recording of the tracer plume, the passive sampling of uranine with charcoals or its long-term measurement with fluorometers. But, for any of these methods, as for many techniques in hydrogeology indeed, the major concern remains the repeatability (or reproducibility) of long-term measurements. Today in hydrogeology, too much data series are unfortunately not fully comparable, and, however, they are compared.

The importance, for the protection of ecosystems, of the relation between flowpaths of groundwater, residence time and exposure conditions has been largely emphasized by Abbott et al. (2016), who recall that suitable tracers must be applied according to the flow, transport and reactive processes. Karst aquifers are probably the most challenging environment where natural and artificial tracers (Mangin et al. 1976; Gaspar and Oraseanu 1987; Dörfliger 2010) can be calibrated together inside the system itself, thus reducing the uncertainties that are inherent to the single use of natural tracers or to systemic lumped parameters approaches. However, this task is made particularly difficult by the high and often unpredictable heterogeneity of karstic features.

\section{Context}

The experimental site is situated along the Ourthe River, $25 \mathrm{~km}$ south of Liège, near the city of Hamoir, on the southern flank of the synclinorium of Dinant (Fig. 1a).

The cave of Fontaine de Rivîre (Fig. 1b, c) is a maze cave, about $1.1 \mathrm{~km}$ long, mostly structurally controlled by bedding and diaclases, ending by a quite unusual lake with crystalline water which has always been fascinating the generations of cavers. The lake is $50 \mathrm{~m}$ long, $25 \mathrm{~m}$ wide, with a funnel shape blocks boulder bottom, whose volume has been estimated to $19,400 \mathrm{~m}^{3}$ (which is also approximately the volume of the air above the lake). The thickness of the limestones below the surface is estimated to be $80 \mathrm{~m}$. The hall of the lake, about $15 \mathrm{~m}$ high, is known for its speleothem wall deposits which are correlated to the successive levels of the Ourthe River.

The cave was discovered in 1968 by the CPL (Centre de Prospection Liégeois). It was early closed and more recently, in 1997, it was given the protective status of a CSIS (Cave of Scientific Interest).

It was formed in Frasnian limestones and dolomites of the Lustin formation (Boulvain et al. 1999, Fig. 1a, b), in pseudo-vertical inverse position, striking NE-SW, as the 
(a)

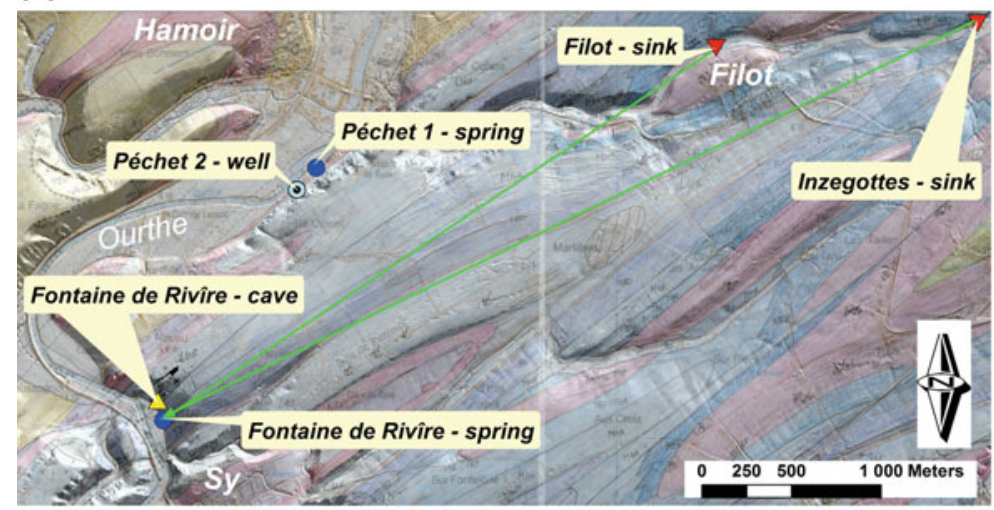

(b)

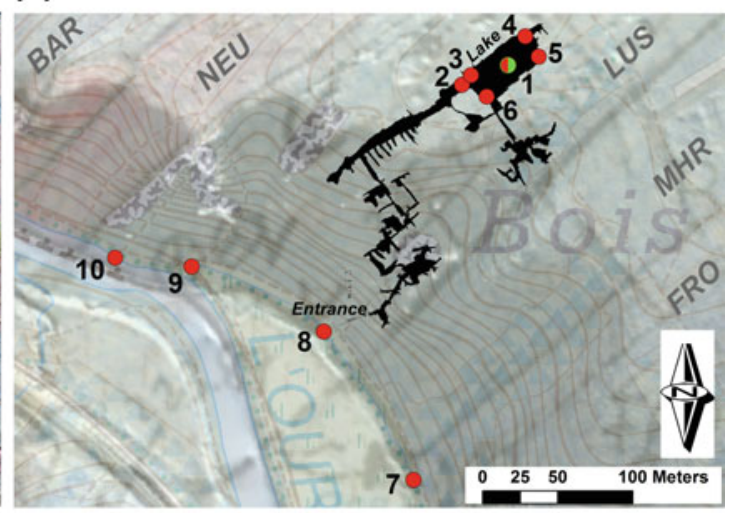

(c)

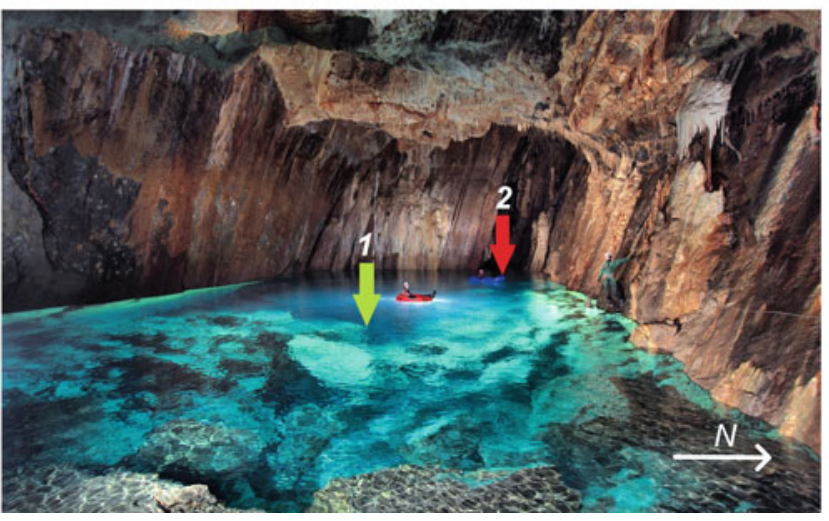

Fig. 1 Situation of the studied area and tracer test. a General situation with geological (after Marion and Barchy in press) and Lidar background. The green arrows indicate connections proven by previous tracer tests. b Situation of the tracer test in the Fontaine de Rivîre cave. 1: centre of the lake - injection point and fluorometer 1; 2: Vineyards gallery-fluorometer 2; 3 to 6: corners; 7: Fontaine de Rivire spring; 8: stream; 9: stream at confluence; 10: Ourthe River; BAR: Barvaux

general structural trend of the area (Dusar and Gullentops 1989; Marion and Barchy in press). The Lustin formation is limited by a fault bringing the limestones of the Mont d'Haurs and Fromelennes formations (of Givetian age) to the south.

The Fontaine de Rivîre spring flows out of the Fromelennes limestones some $100 \mathrm{~m}$ south of the entrance of the cave, with which it is now demonstrated that there is no connection. A shale layer is, however, separating the two systems.

A tracer test was done by Nys in 1929, from the Inzegottes swallow hole. This tracing was repeated in 1968 by the speleological association Centre de Prospection Liégeois. More recently (Meus 2006), in May 2006, both Filot and Inzegottes swallow holes were traced in the frame of a study for the restoration of the waterworks of Péchet 1 and 2 in Hamoir. An exclusive connection between the swallow holes and the Fontaine de Rivire spring was established in each case, with transit velocities, in high stage of May 2006, of 52 and $73 \mathrm{~m} / \mathrm{h}$, respectively. However, no connection was ever formation; NEU: Neuville formation; LUS: Lustin formation; MHR: Mont d'Haurs formation; FRO: Fromelennes formation. The meteorological station of Ouffet is outside of the map (to the North) just a few kilometres from the cave. c Lake of Fontaine de Rivîre (photograph P. De Bie). The green arrow indicates the position of the injection point (3 $\mathrm{m}$ depth) and the fluorometer 1 (12 $\mathrm{m}$ depth). The red arrow is for fluorometer 2 (2 $\mathrm{m}$ depth) found towards the lake in the cave, though the lake was carefully controlled by charcoal detectors.

Godissart (1994) found that the temperature of the atmosphere above the lake was higher than the average of the other Belgian caves, that is to say $11.6^{\circ} \mathrm{C}$ instead of $9.2{ }^{\circ} \mathrm{C}$. He found that the stationarity of this temperature could be due to the stationarity of thermal fluxes from the lake itself. The author also assumes some regulation exchanges of $\mathrm{CO}_{2}$ between the lake and the air above that indicate an important confinement with a saturation of water regarding the calcite equilibrium. This confinement would be in accordance with the lack of a good connection between the lake and the surrounding aquifer.

Godissart also made several altimetric measurements with a tube level to find that the spring of Fontaine de Rivîre was $4.5 \mathrm{~m}$ higher than the normal level of the lake.

Ek and Godissart (2009) have recorded the evolution of the concentration of $\mathrm{CO}_{2}$ in the air above the lake. They measured an increase in $\mathrm{CO}_{2}$ lower than in the majority of the other caves studied in Belgium. The concentration in 
2014 (Godissart, oral communication based on a last measurement done by O. Stassart) was around 10,000 ppm, that is to say twice the concentration measured in 1970. Despite the fact that measurements with such an interval should of course be considered with special care, and that continuous monitoring of the $\mathrm{CO}_{2}$ has not been done until now, we can make the assumption that the specific confinement of the lake should also be responsible for a great stability of the air above, and thus a good coherence with climatic trends. The main intriguing questions about the lake have always been where water was coming from, where it was going to, and even whether it was moving somewhere, and perhaps during which period of the year. The great stability of the physico-chemical parameters (water temperature and conductivity), even when significant fluctuations of the water level occur, together with the latest questions, were the main reasons motivating the tracer test described in this work.

\section{Methods}

A pressure and temperature probe (In Situ, TROLL 500) was installed at the beginning of 2007 in the water of the main gallery leading to the lake (point 2 on Fig. 1b, c). This probe was doubled by a second probe between 2010 and 2014 .

In 2008, a topographic survey was made with the support of the Geotechnical Direction of the Public Service of Wallonia (DGO1-61) using a differential GPS outdoor and a level tube improved by a TROLL pressure probe at the end for the underground levelling. The survey confirmed the higher level of the Fontaine de Rivîre spring (+121.92 m a.s. 1. for the reference) compared to the lake $(+119.46 \mathrm{~m}$ a.s.l. for the reference bolt where the support of the probe is attached, the lake being $1.22 \mathrm{~m}$ lower than the reference at that time on 26.10 .2008 at $16: 25)$. The confluence of the spring stream with the Ourthe River (point 9 on Fig. 1b) is at $118.30 \mathrm{~m}$ a.s.1.

The tracer used for the test was a liquid uranine (FLUORESCEIN LT SOLUTION 67\%-Alpasud). The fluorescence efficiency of the tracer was calibrated against a reference uranine (FLUORESCEIN SODIUM-Fisher Chemicals) also used for calibration of the fluorescence spectrophotometer (Hitachi F-2500), and the content was in fact $41 \%$. Two field fluorometers (GGUN-FL30 from Albillia) were recording three fluorescence signals (with an excitation LED at $470 \mathrm{~nm}$ for uranine detection), turbidity, temperature and conductivity. The data of these fluorometers were stored with TRMC-5 (Tetraedre) dataloggers.

The installation of the tracing material was made one week before the test, to avoid any flow disturbance of the lake during the injection. The injection tube was suspended at $3 \mathrm{~m}$ depth in the middle of the lake (point 1 on Fig. 1b, c). One of the fluorometer probes was suspended at the vertical of the injection point, at about $12 \mathrm{~m}$ depth. The other fluorometer was immersed at the same approximate depth in the main gallery (point 2 on Fig. 1b, c).

The injection of $61 \mathrm{~g}$ of uranine (149 $\mathrm{g}$ of product) was made on 22.03.2017 at 14:53, in approximately $1.5 \mathrm{~min}$, with a Knf $12 \mathrm{~V}$ membrane pump (100 ml/min) with a pressure regulator of 3 bars at the end of the injection line.

The sampling interval of the fluorometers was set to 1 min during the day of the injection and then to $15 \mathrm{~min}$ until the end of the test on 4 February 2018.

Pictures of the tracer plume (Fig. 2) were taken every $5 \mathrm{~s}$ during 8:40 by a GoPro Hero camera $\left(120^{\circ}\right.$ angle) fixed at the top of the chamber. Light was provided by five spots (4700 lm) distributed around the lake just above the surface and powered by a generator outside the cave.

Carbon detectors (charcoal activated ref. 1.02514.5000, granularity $1.5 \mathrm{~mm}$, from Merck) were placed at the four

Fig. 2 Progression of the tracer plume towards WSW (processed from camera recordings)

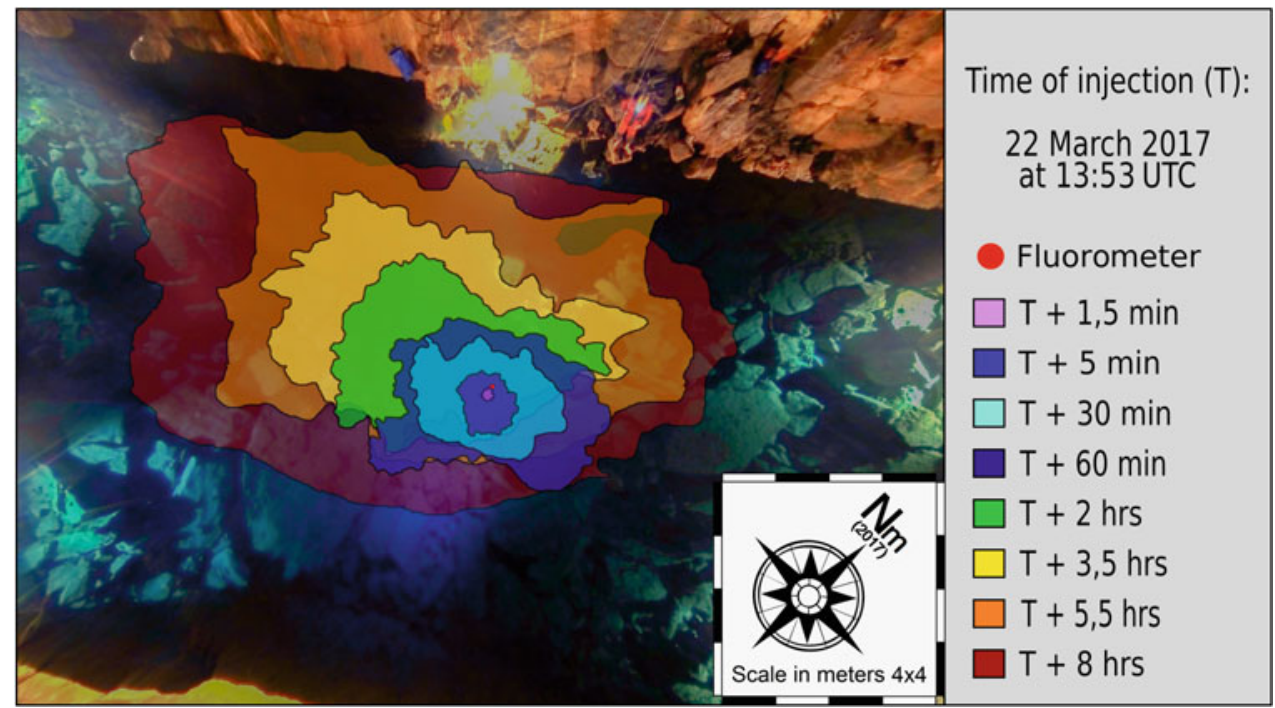


corners of the lake (points 3, 4, 5 and 6 in Fig. 1b) and close to the fluorometer in the main gallery (point 2 in Fig. 1b, c). They were replaced with intervals between 2 weeks and more than 1 month. The water of the lake was sampled for laboratory analyses at the same place and interval as the detectors.

Outside sampling was also done at the Fontaine de Rivîre spring (point 7 on Fig. 1b), along its stream in front of the cave entrance (point 8 on Fig. 1b), in the stream just before its confluence with the Ourthe River (point 9 on Fig. 1b), along the right bank of the Ourthe River (point 10 on Fig. 1b) and at the overflows of the Péchet 1 and 2 waterworks (Fig. 1a).

The analyses of uranine were performed with a Hitachi F-2500 fluorescence spectrophotometer. All intensities at uranine wavelengths $(490 / 591 \mathrm{~nm})$ were corrected according to instrument long-term stability using a solid standard (Gaigalas et al. 2001) made of epoxy resin with addition of a fluorescent dye (epodye) in a PS supporting cell. Fluorometer intensities were calibrated according to water sample concentrations.

Extraction from charcoals was made by a solution of $\mathrm{KOH} 5 \% \mathrm{Vol}$ in pure ethanol, followed by spectrofluorimetric quantification with the same calibrated fluorescence spectrophotometer.

Rainfall and level of the Ourthe (intervals of $1 \mathrm{~h}$ ) were provided by DGO2 (Public Service of Wallonia), rainfall from the station of Ouffet situated a few kilometres from the cave, and level from the station of Hamoir (Fig. 1a).

\section{Results}

\section{Tracer Test}

Though the injection was as smooth as possible, the injection (at a depth of $3 \mathrm{~m}$ ) created a mushroom cloud. It appeared rapidly that a deal of the tracer was sinking towards the bottom of the lake while a main cloud (plume) started a very slow horizontal displacement (Fig. 2) towards WSW, in the direction of the main gallery (Wineyards gallery) and the Ourthe Valley.

The fluorometer situated $9 \mathrm{~m}$ below detected the tracer after $12 \mathrm{~min}$, reaching directly the maximum concentration of $2.991 \mathrm{ppm}$ (Fig. 3a). The cloud was filmed during $8.4 \mathrm{~h}$.

At the centre of the lake, the breakthrough of the tracer remained quite chaotic (Fig. 3a, b), what can be partially due to a limited diffusion inside the cell of the fluorometer. It took about one month (Fig. 4) to reach a more homogeneous behaviour flowed by a slow concentration decrease. The breakthrough was more regular at point 2 situated at about $30 \mathrm{~m}$ downwards the injection point. The first arrival was $21.12 \mathrm{~h}$ after the injection, which gives a maximum velocity
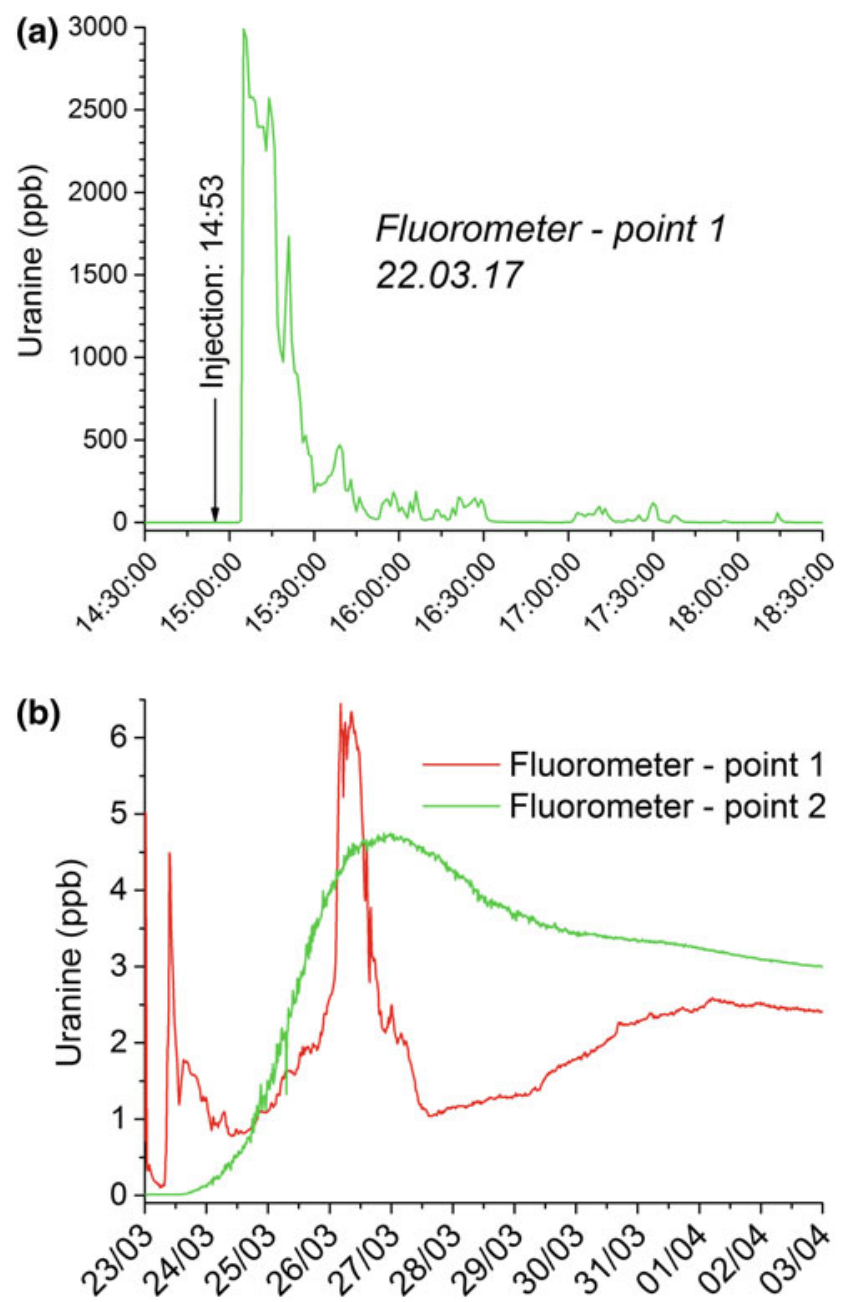

Fig. 3 Breakthrough of uranine. a Recorded during the first hours by the fluorometer at the centre of the lake (point 1 on Fig. 1b, c). The fluorescence was measured with excitation at $525 \mathrm{~nm}$ to work around the saturation at $470 \mathrm{~nm}$. b Recorded during the first 13 days by the fluorometers at the centre of the lake (point 1 on Fig. 1b, c) and in the main gallery (point 2 on Fig. 1b, c)

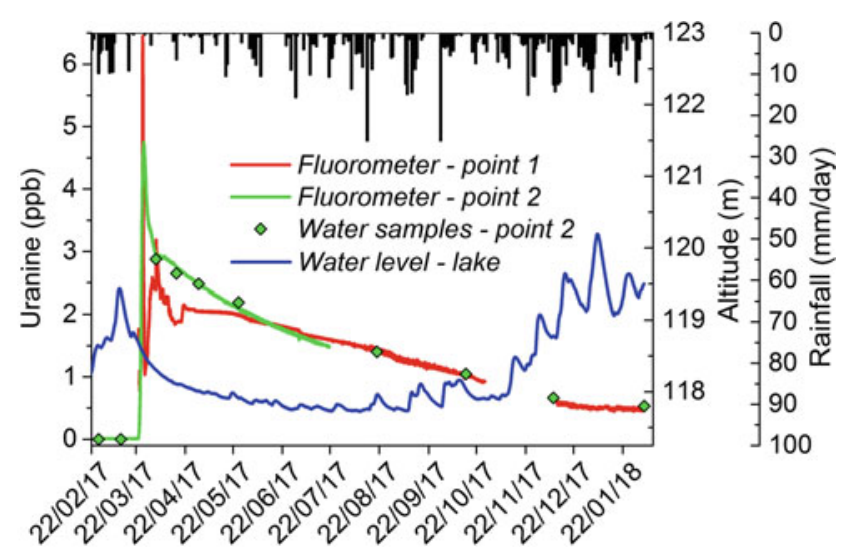

Fig. 4 Breakthroughs of uranine recorded during the whole experiment (fluorometer at the centre of the lake and manual sampling until 4 February 2018, fluorometer in the main gallery until 22 July 2017), compared with altitude of the lake and daily precipitations 
of $1.42 \mathrm{~m} / \mathrm{h}$. The peak was reached after $104.78 \mathrm{~h} \mathrm{(a}$ velocity of $0.29 \mathrm{~m} / \mathrm{h}$ ). Assuming a section of $187.5 \mathrm{~m}^{2}$ and a uniform velocity, this would give a flux of $54.4 \mathrm{~m}^{3} / \mathrm{h}$ (15 l/s). Soon after the peak, there was a change in the behaviour of the tracer which followed an asymptotic trend to a linear decrease until the end of the test on 4 February 2018 (Figs. 3b and 4). We make the hypothesis that this change can be due to a change in the flow regime of the lake, which was until then under the influence of the high stage of mid-March, and whose effect finally ceased at the beginning of April, without any rain event (see responses of the lake below). One can also consider that the start of the linear trend, with the same concentration at the centre of the lake and in the gallery, would correspond to a complete mixing of the tracer in the lake and eventually connected water. Knowing the concentration at that moment (around $2 \mathrm{ppb}$ ), the $61 \mathrm{~g}$ injected would uniformly reach a volume of $30,500 \mathrm{~m}^{3}$ which is slightly higher than the estimated volume of the lake. The additional volume involved can be stored in some inaccessible conduits, or due to an underestimated volume, but this also means that the lake is not connected to any other relevant volume of water in its vicinity, and it is in agreement with the initial hypothesis of the confinement of the lake. We assume that we observed a transitional regime of the lake with a convective component at the beginning of the experiment (displacement of the plume of tracer) followed by a diffusive phase afterwards. Anyway, this diffusive phase is a challenge for understanding. Molecular diffusion lonely cannot explain the initial evolution of the plume of the tracer. Using for instance the value of the diffusion of fluorescein in water given by Culbertson et al. (2002), $4.25 \times 10^{-6} \mathrm{~cm}^{2} \mathrm{~s}^{-1}$ at $25^{\circ} \mathrm{C}$, even with a correction of the effect of temperature, and using an approximated Fick's law, the mean displacement of the tracer should be less than $1 \mathrm{~cm}$ after $8 \mathrm{~h}$, while the real displacement was in reality several metres during that time.

The concentration decreased regularly after complete mixing in the lake, so that we should assume the dilution by a given volume of external water (or another unknown effect, any degradation of uranine being not supposed to occur in the absence of light and presumably low microbiological activity, and long-term adsorption being not known as well). If we look at the behaviour of the tracer during the period of recharge in autumn and winter (Fig. 4), no variation can be seen at any moment (it even seems to stabilize at the end of the experiment). This is quite contradictory with the influence of the recharge noticed at the beginning of the test. If we assume the lake rising several times by one to two metres, this would allow for the renewal of the lake of minimum a quarter of its initial volume. So, the concentration should have decreased by at least a factor 4 . This was not the case during the recharge period, and we should normally assume another mechanism for the rising of the lake (see the lake responses hereafter). We should remark here that this factor 4 would be the same as the factor of dilution that the tracer effectively underwent, but in this case during the whole year. This volume of dilution corresponds to an average annual discharge of the lake of about $0.57 \mathrm{~m}^{3} /$ $\mathrm{h}(0.16 \mathrm{l} / \mathrm{s})$. This value is 100 times lower than what was calculated according to the velocity of the tracer at the beginning of the tracer test.

Water (Fig. 5a) and charcoals (Fig. 5b) sampled in the gallery and in the four corners of the lake are complementing the measurements made by the fluorometers. Water concentrations show that the tracer is progressively more homogeneous in the whole lake along time. The first sampling on 3 April shows that the upward side of the lake (points 4 and 5 on Fig. 1b) contains less tracer, according to the initial displacement towards SW and the lake which was not yet homogenized. The analyses of the samples of 2 July must not be taken into account because they may have suffered an instrumental problem (a lamp default).

Dunn (1961) and later Lallemand and Paloc (1964) suggested the charcoal method as a convenient sampling technique for fluorescent tracers in hydrogeology. Regarding the fluorescein, Mathey (1971) also tested the method at the laboratory scale only. Smart and Simpson (2002) reported a field study on the problem of the background (and the potential use of charcoals for sampling fluorescent compounds). Nevertheless, the charcoal method is nowadays despised (Mondain and Muet 2008) due to the possible errors when it is misused (for instance without spectral determination) or not validated through other sampling methods. In this study, we intended to test the ability of the method for a quantitative approach, for uranine specifically, at field scale, long-term scale also, and with relatively well-controlled conditions. The concentrations of uranine in the eluents of the charcoal bags immersed in the lake are shown in Fig. 5b. The analyses confirm the lower fluxes of uranine upwards at the beginning of the experiment. They also demonstrate that the duration of the immersion is a determinant factor. While the amount of desorbed uranine decreases after the injection with 2 weeks sampling interval, a longer sampling interval (above 1 month) gives again higher concentrations, proving a complex kinetic of fixation that could take longer than assumed before. Our own experience of this technique let us believe that the quite high dispersion of the results may be due to insufficiently controlled parameters (thus reproducibility) during the analytical process of extraction. The method would obviously require further validation tests to become more reliable for fluorescent dye traces.

We will close this section by mentioning that, despite regular samples and conjunctional use of water and charcoal 

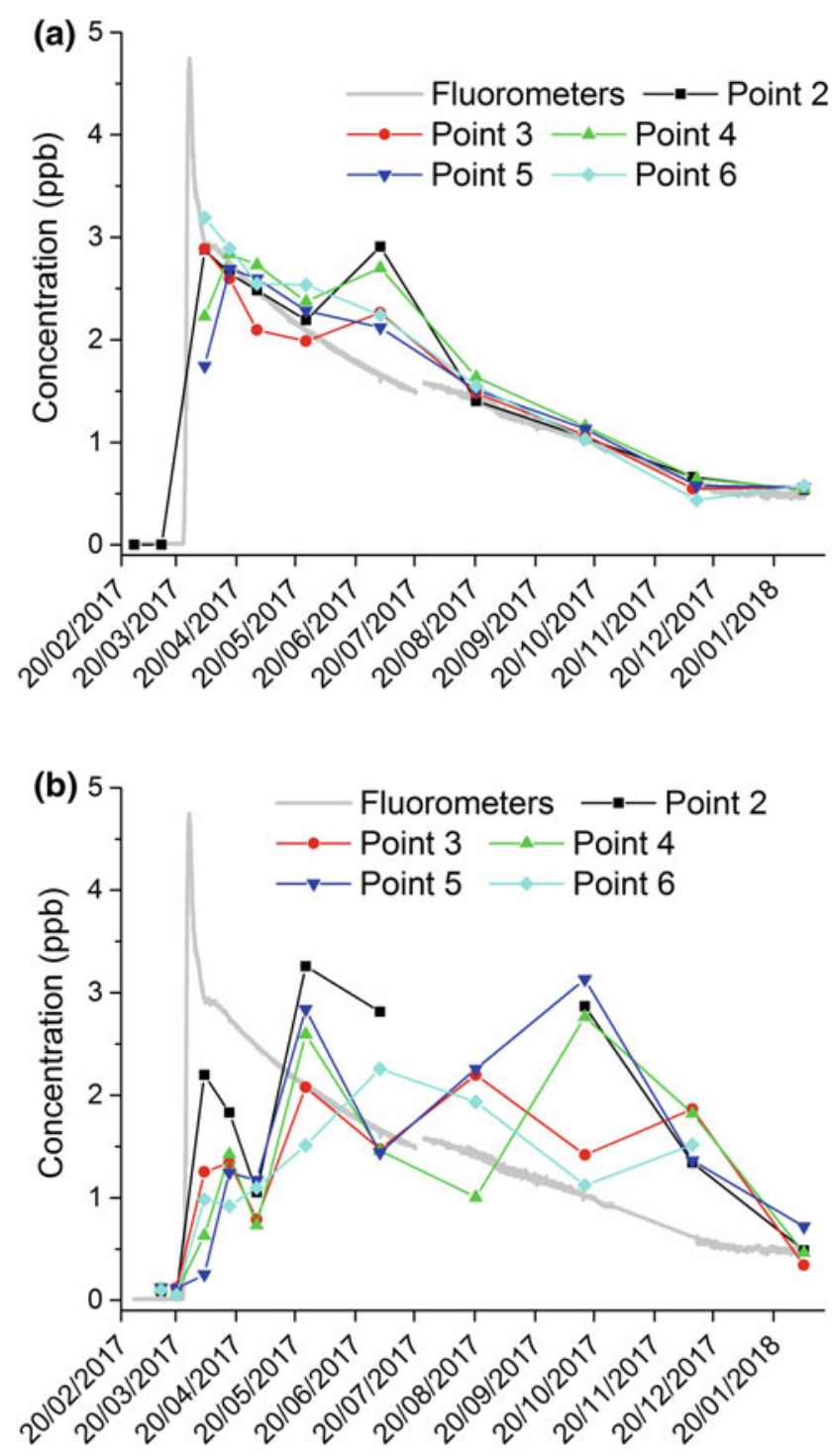

Fig. 5 Concentrations of uranine. a In water samples collected in the main gallery (point 2 on Fig. 1b, c) and at the four corners of the lake (points 3 to 6 on Fig. $1 \mathrm{~b}$ during the experiment, compared with fluorometer measurements (first part from fluorometer in the gallery, second part from the fluorometer in the centre). $\mathbf{b}$ In the eluent of active charcoal detectors collected in the main gallery (point 2 on Fig. 1b, c and at the four corners of the lake (points 3 to 6 on Fig. 1b) during the experiment, compared with fluorometer measurements (first part from fluorometer in the gallery, second part from the fluorometer in the centre)

samples for precise detection, uranine could never be found outside, nor in the Fontaine the Rivîre spring (theoretically it was however impossible), nor in the Ourthe (where it can underflow at extremely low concentrations), nor in the Péchet waterworks. These results are obviously not surprising after what was observed in the lake.

\section{Natural Responses}

The apparent contradiction between the lake level variation and its high stability regarding any other parameter motivated the tracer test. The temperature in particular (Fig. 6) was showing a continuous increase since the beginning of its recording in 2007.

Despite the specification of $0.1{ }^{\circ} \mathrm{C}$ accuracy, obviously, the probe TROLL always kept a better sensitivity. This was proved by a second probe installed at the same point between 2010 and 2014, as well as by the temperature recorded by the fluorometers during the tracer test. The decennial increase of $4.6{ }^{\circ} \mathrm{C}$ seems compatible with the trend of $4{ }^{\circ} \mathrm{C}$ recorded at the meteorological station of Uccle for the mean annual temperature during the years before 2016 (Climat.be 2018). The advantage of the signal of the lake of Fontaine de Rivire is obviously the total absence of background noise. This confirms the role of filter that cave environments (and aquifers) may play in a precise determination of climate change. So, caves would not only represent a tool for palaeoclimate studies but also for the present evolution. The same idea as for temperature can be advanced concerning $\mathrm{CO}_{2}$ concentrations in such a cave. The records of temperature in the lake show that it was increasing exponentially until the years 2010-2011. Since then, the temperature follows a more linear trend. Meus et al. (2014) already noticed a break in 2010-2011 in temperature and hydrologic behaviour of several karst springs in Belgium.

The fluctuations of the lake do not significantly affect the temperature, what is in agreement with the very low renewal of the lake indicated by the tracer test. Sometimes, some fluctuations of the temperature can be observed during the most important risings of the lake but their amplitude of a few thousandths of degree is probably not significant in that case.

We can also already observe (Fig. 6) a strong apparent correlation (not only from an event point of view but also regarding the amplitudes) between the level of the lake and the level of the Ourthe River recorded downward the site.

A closer look at the responses of the lake (Fig. 7) confirms the link between the level of the river and that of the lake with a given lag and damping of the pulses. This process could be statistically quantified for the whole period of observation (2007-2018), using correlation analyses (Mangin 1984).

The simple correlograms shown (Fig. 8a), processed with $\mathrm{R}$ software, using a lag of $1 \mathrm{~h}$ (data regularly interpolated), indicate a quite high memory effect of lake level, and a lower memory of the levels in the Ourthe River. The cross-correlograms were also computed (Fig. 8b) between assumed causes and the responses. It shows maxima of responses to rainfall of 32 and $104 \mathrm{~h}$, respectively, for the 
Fig. 6 Time series of the water temperature of lake, altitudes of lake and Ourthe River in Hamoir, and rainfall in Ouffet
Fig. 7 Temperature of lake, altitudes of lake and Ourthe River in Hamoir, and rainfall in Ouffet for the period from 20 February until 1 May 2017. The insert shows the semi-diurnal fluctuations
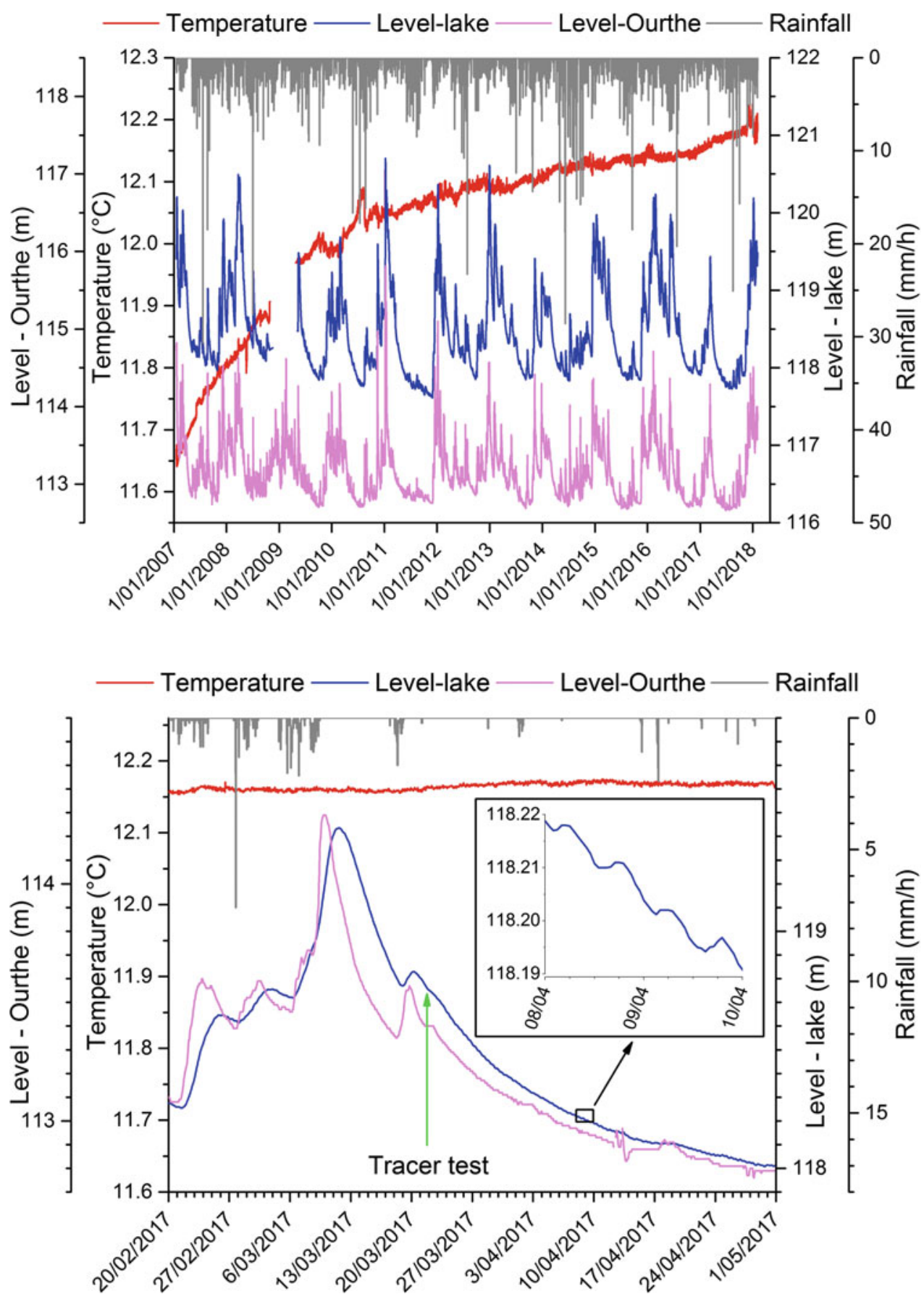

level of the Ourthe and the level of the lake. The delay between the level of the Ourthe and the level of the lake is only $34 \mathrm{~h}$, with a quite high correlation. This indicates most probably a causal relation between both levels and it gives us one additional element to understand the recharge of the lake. We assume that the main cause of the variations of the level of the lake is not only the recharge by water itself (through infiltration or exchanges with high transmissivity karst conduits), but it would be mainly due to a complex transfer of pressures from the neighbouring water table, with very low exchanges of matter indeed.

Another key for understanding the confinement of the lake can be the tidal variations that are clearly seen on the level recordings during undisturbed periods (insert on Fig. 7) where cyclic fluctuations of about $1 \mathrm{~cm}$ are detected. A Fourier analysis was computed with the Origin software for the levels of the lake. Four frequencies went out of the spectrum (Fig. 9). 

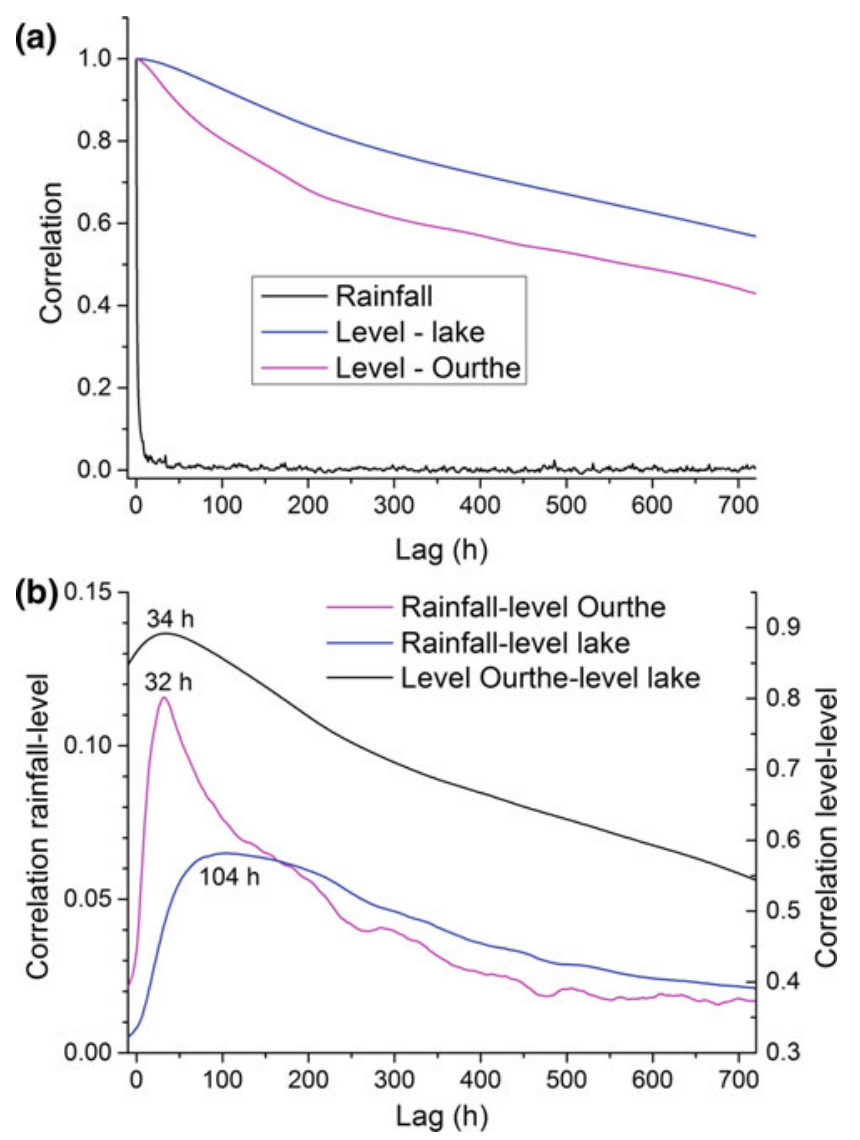

Fig. 8 a Simple correlograms of rainfall and water levels. b Cross-correlograms between rainfall and levels, and between levels of lake and Ourthe

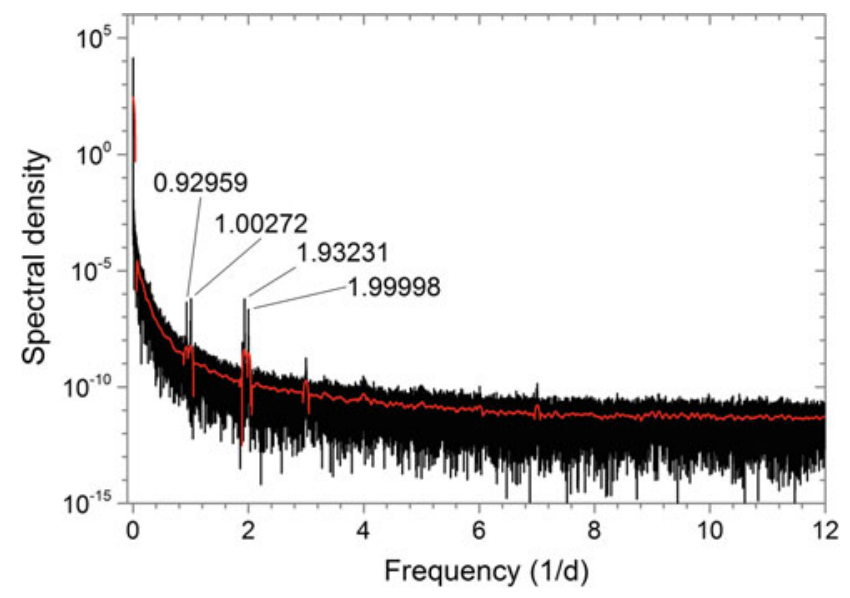

Fig. 9 Fourier analysis of water levels of the lake with gravitational semi-diurnal and diurnal frequencies

These are very close to the four main gravitational lunar and solar periodicities mostly known as responsible for tidal effects in Belgium (respectively, $\mathrm{K} 1$ at $1.00278, \mathrm{O} 1$ at $0.92963, \mathrm{M} 2$ at 1.93288 and S2 at 2.00000, Van Ruymbeke et al. 2007). Such periodicities have been found in other carbonate environments (springs, boreholes, Delvaux and Steisel 2009). The confinement of the lake of Fontaine de Rivîre is suggesting us that a detailed analysis of the tidal and barometric effects would be useful to understand how a confined auxiliary system is exchanging energy with its surroundings.

\section{Conclusion}

Single-point dilution tracer test offers an interesting alternative where classical tracer tests are no more relevant, especially for the most confined auxiliary systems of many karst aquifers. In most of these aquifers, the volume of low flow water can be far higher than inside active conduits, while playing a crucial role for the sustainability of the aquifer.

Such a tracer test was successfully achieved using a low quantity of uranine in the lake of Fontaine de Rivîre. The expansion of the tracer could be followed at different time scales during 1 year, using video recordings, fluorometer measurements, as well as water and charcoal samplings.

A slow flow (in the order of magnitude of $1 \mathrm{~m} / \mathrm{h}$ ) of the lake could be detected and some mixing processes identified. However, this flow probably decreased very early after the injection. The dilution of the tracer along the year indicates a mean discharge of the lake of about $0.16 \mathrm{l} / \mathrm{s}$.

The behaviour of the tracer, together with the natural responses of the lake, indicates that the system is not physically filling and emptying during high stages. The fluctuations of the level of the lake are due to pressure transfers from the surrounding water table regulated by the base level of the Ourthe Valley, with a mean time delay of $32 \mathrm{~h}$.

From a methodological point of view, this research is also a contribution to tracer sampling techniques, among others the video monitoring and the active charcoal sampling for which a quantitative validation could be done for the first time at a field scale.

Thanks to its high confinement, the lake is also a real filter for climatic responses (temperature, $\mathrm{CO}_{2}$, etc.) at the condition that long-term recordings could be gained by insuring a good reproducibility. This lake could thus become an efficient observatory to understand both climatic evolution and resources of aquifers.

Acknowledgements This research was not supported by any fund. This is a good reason why we are especially grateful to those people who contributed to the achievement. The owner of the property Ranscelot is acknowledged for authorizing the access to the cave and allowing it to be protected for scientific studies. J.-M Marion provided great help with his feeling of "real" geologist and providing unpublished maps. Johan Derouane contributed to the GIS management. The lake has been photographed many times, but the best picture is here 
included thanks to Paul De Bie. Finally, I would like to express my gratitude to Alain Mangin ( $\dagger$ ) and to Michel Bakalowicz who showed me the way and motivation for understanding karst aquifers.

\section{References}

Abbott B, Baranov V, Mendoza-Lera C et al. (2016) Using multi-tracer inference to move beyond single-catchment ecohydrology. Earth-Science Reviews, 160 (2016): 19-42

Bakalowicz M (1999) Connaissance et gestion des ressources en eaux souterraines dans les régions karstiques. Bassin Rhône-Méditerranée-Corse, Guide Technique no. 3, juin 1999

Bakalowicz M, Crochet P, D'Hulst D et al. (1994) High discharge pumping in a vertical cave, fundamental and applied results. In: Basic and applied hydrogeological research in French karstic areas. Cost 65 Action. Hydrogeological aspects of groundwater protection in karstic areas. Crampon and Bakalowicz ed. European Commission, pp 93-110

Boulvain F, Bultynck P, Coen M et al. (1999) Les formations du Frasnien de la Belgique. Memoirs of the Geological Survey of Belgium, no. 44-1999: 1-125

Climat.be (2018) Le climat en Belgique. Observations en Belgique. Température. http://www.climat.be/fr-be/changements-climatiques/ en-belgique/observations-en-belgique. Accessed 19 March 2018

Culbertson CT, Jacobson SC, Ramsey JM (2002) Diffusion coefficient measurements in microfluidic devices. Talanta 56 (2002): 365-373

Delvaux M, Steisel M (2009) Etude de l'influence de la marée terrestre sur les variations piézométriques de la nappe de la craie à Spiennes (Mons). Mémoire, UCL Louvain-la-Neuve

Dewaide L, Collon P, Poulain A et al. (2017) Double-peaked breakthrough curves as a consequence of solute transport through underground lake: a case study in the Furfooz karst system, Belgium. Hydrogeology Journal. Published on-line 26 Sep 2017

Dörfliger N (2010) Guide méthodologique. Les outils de l'hydrogéologie karstique. Avec la participation de Ph. Crochet, R. Guerin, N. Jozja, B. Marsaud, P.-H. Mondain, Ph. Muet, V. Plagnes. BRGM RP-58237-FR

Dunn JR (1961) Nouveau procédé de détection de la fluorescéine. Spelunca 4ème série: 1-26

Dusar M, Gullentops F (1989) Stratigraphie et tectonique dans la region d'Hamoir-sur-Ourthe. Aardkundige mededelingen vol.4 Leuven University Press 1989

Ek C, Godissart J (2009) Extreme increase of $\mathrm{CO}_{2}$ in Belgian caves. Earth Sciences, 2009 ICS Proceedings, 15th International Congress of Speleology: 1467-1473

Gaigalas AK, Li L, Henderson O et al. (2001) The development of fluorescence intensity standards. J. Res. Nat. Inst. Stand. Technol. 106: $381-389$

Gaspar E, Oraseanu I (1987) Natural and artificial tracers in the study of the hydrodynamics of karst. Theoretical and Applied Karstology, vol.3, 1987: 32-106

Godissart J (1994) Le cycle annuel des températures et du $\mathrm{CO}_{2}$ dans la grotte de Fontaine de Rivîre à Hamoir (Belgique). Publ. Serv. Géol. Luxembourg, vol. XXVII, Comptes-rendus du colloque international de karstologie à Luxembourg, 1994: 179-185

Grasso DA, Jeannin PY, Zwahlen F (2003) A deterministic approach to the coupled analysis of karst springs' hydrographs and chemographs. Journal of Hydrology 271 (2003): 65-76

Guizerix J, Margrita R, Niemi A (1990) Tracer methodology. In: Guidebook on radioisotope tracers in industry. IAEA Vienna 1990. Technical reports series no. 316: 39-92
Jeannin PY (1996) Structure et comportement des aquifères karstiques. Thèse. Université de Neuchâtel

Kiraly L (2003) Karstification and groundwater flow. Speleogenesis and Evolution of Karst Aquifers, 1(3), September 2003: 1-25

Lallemand A, Paloc H (1964) La méthode de détection au charbon actif pour les opérations de traçage à la fluorescéine. Quelques exemples d'application. BRGM DS 64 A47: 1-15

Mangin A (1975) Contribution à l'étude hydrodynamique des aquifères karstiques. Université de Dijon. Laboratoire du CNRS Moulis. Thèse publiée dans les Ann. de Spéléologie, 1974 no. 29 (3): 283 332, 1974 no. 29 (4): 495-601, 1975 no. 30 (1): 21-124

Mangin A (1984) Pour une meilleure connaissance des systèmes hydrologiques à partir des analyses corrélatoire et spectrale. Journal of Hydrology, 67 (1984): 25-43

Mangin A (1994) Karst hydrogeology. In: Groundwater Ecology, Academic Press, pp 43-67

Mangin A, Molinari J, Paloc H (1976) Les traceurs en hydrogéologie karstique. Leur apport à la connaissance des réservoirs aquifères calcaires. La Houille Blanche No. 3-4 1976: 261-267

Marion JM, Barchy L (in press) Carte géologique de la Wallonie à l'échelle 1/25.000. Hamoir - Ferrières no. 49/5-6 et sa notice explicative. SPW/Editions, Cartes. DGARNE, Jambes (Namur). 1 carte couleur +1 notice explicative

Marsaud B (1996) Les pompages en aquifère karstique. Une démarche d'interprétation des essais adaptée au karst. In: Pour une gestion active des ressources en eau d'origine karstique. BRGM Département Eau (1998). Rapport BRGM R 40126, pp 177-197

Martel EA (1921) Nouveau traité des eaux souterraines. Paris, Librairie Octave Doin, Gaston Doin Ed., 1921

Mathey B (1971) La méthode au charbon actif dans les essais de coloration à la fluorescéine. In: Actes du 4ème Congrès suisse de Spéléologie, Neuchâtel, septembre 1970, pp 53-61

Meus P (1997) Méthode d'évaluation de la vulnérabilité des aquifères karstiques utilisant le traçage en continu. In: La géologie de l'ingénieur et l'eau dans le sous-sol. Colloque National. Leuven. 18-20/11/1997, 22/1-10

Meus P (2006) Multitraçage sur le site de la source Péchet (Hamoir). Rapport EWTS 07-2006

Meus P, Moureaux P, Gailliez S et al. (2014) In situ monitoring of karst springs in Wallonia (southern Belgium). Environ Earth Sci (2014) 71:533-541

Mondain PH, Muet P (2008) Proposition d'une grille d'évaluation des résultats des traçages en milieu karstique (au moyen de traceurs fluorescents). In: CFH Colloque Hydrogéologie et Karst au travers des travaux de Michel Lepiller, 17 mai 2008, pp 191-205

Müller I (1981) L'eau dans les roches calcaires. Bulletin de la société Fribourgeoise des Sciences Naturelles. 70 (1/2) - 1981: 12-20

Novakowski KS, Lapcevic PA, Voralek et al. (1995) Preliminary interpretation of tracer experiments conducted in a discrete rock fracture under conditions of natural flow. Geophysical Research Letters, vol.22, No. 11, June 1, 1995: 1417-1420

Smart CC, Simpson B (2002) Detection of fluorescent compounds in the environment using granular activated charcoal detectors. Environmental Geology (2002) 42: 538-545

Van Ruymbeke M, Zhu P, Cadicheanu N et al. (2007) Very weak signals (VWS) detected by stacking method according to different astronomical periodicities (HiCum). Nat. Hazards Earth Syst. Sci., 7: $651-656$

Worthington SRH (2003) A comprehensive strategy for understanding flow in carbonate aquifer. Speleogenesis and Evolution of Karst Aquifers, 1(1), January 2003: 1-8 